\title{
P059: MRSA surveillance in a Danish region
}

\author{
RA Leth", The MRSA Section Group \\ From 2nd International Conference on Prevention and Infection Control (ICPIC 2013) \\ Geneva, Switzerland. 25-28 June 2013
}

\section{Introduction}

Surveillance of MRSA is an important topic in infection control. In our region we have monitored new MRSA cases since 2010.

\section{Objectives}

The aim was to describe surveillance of MRSA in a Danish region with three clinical microbiology departments. The population in the region constitutes approximately 1.2 million inhabitants.

\section{Methods}

Using data from a laboratory information system (MADS) data on new MRSA episodes at each of the three clinical microbiology departments was generated monthly. Data was entered into a common MRSA surveillance database for further follow-up.

\section{Results}

The number of incident MRSA patients has still been increasing since 2010.

In 2012 we registered 225 new MRSA patients in our region, an increase of $24 \%$ compared with the number of new MRSA patients in 2011. The number of new cases of livestock MRSA (clonal complex CC398) has also been increasing, from 40 cases in 2011 to 65 cases in 2012.

We did not see any hospital clusters either in 2011 nor in 2012.There were 32 family clusters each including two to five persons.

Totally, more than $62 \%$ of the incident patients had an infection with MRSA. Forty-five per cent were exposed by family-members or pigs; in $16 \%$ exposure was unknown; $8 \%$ were supposedly exposed on holidays outside Europe.

Department of Clinical Microbiology, Aarhus University Hospital, Aarhus, Denmark

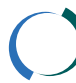

\section{and take full advantage of:}

- Convenient online submission

- Thorough peer review

- No space constraints or color figure charges

- Immediate publication on acceptance

- Inclusion in PubMed, CAS, Scopus and Google Scholar

- Research which is freely available for redistribution Submit your manuscript at
www.biomedcentral.com/submit

C Biomed Central 